\title{
The Prospects and The Competitiveness of Textile Commodities and Indonesian Textile Product in the Global Market
}

\author{
Dwi Prasetyani ${ }^{1 *}$, Ali Zainal Abidin², Nanda Adhi Purusa ${ }^{3}$, Fahrein All Sandra ${ }^{4}$ \\ *Corresponding author
}

\begin{abstract}
This study has two objectives: first, to test the competitiveness of Textile Commodities and Indonesian Textile Product (TPT) in the global market and identify the prospects of the new export markets. Second, identify the competitiveness of the textile industry using case studies in the Solo Raya region. The Revealed Comparative Advantage (RCA) and Export Product Dynamics (EPD) methods are using in this study. The results show that Indonesian TPT commodities have a lost opportunity category in the central export destinations countries, such as a decline in market share. Indonesian TPT commodities have prospects in Austria, Canada, Finland, Norway, Portugal, Qatar, and Sweden due to competitiveness and domination in the market. Besides, the condition of the Indonesian textile industry competitiveness shows low competitiveness in terms of factor conditions, demand conditions, supporting and related industries, strategy, structure, and competition that are components of Porter's diamond model.
\end{abstract}

Keywords: competitiveness, textile products, comparative advantage, export product dynamics, Porter's diamond model

JEL Classification: L6, L67

\begin{abstract}
Abstrak. Penelitian ini memiliki dua tujuan: pertama, untuk menguji daya saing komoditas tekstil dan produk tekstil Indonesia (TPT) di pasar global dan mengidentifikasi prospek pasar ekspor baru. Kedua, mengidentifikasi daya saing industri tekstil menggunakan studi kasus di wilayah Solo Raya. Metode revealed comparative advantage (RCA) dan ekspor produk dinamika (EPD) digunakan dalam penelitian ini. Hasilnya menunjukkan bahwa komoditas TPT Indonesia memiliki kategori lost opportunity di negara tujuan ekspor utama, seperti penurunan pangsa pasar. Komoditas TPT Indonesia memiliki prospek di Austria, Kanada, Finlandia, Norwegia, Portugal, Qatar, dan Swedia karena daya saing dan dominasi yang kuat di pasar. Selain itu, kondisi daya saing industri tekstil Indonesia menunjukkan daya saing yang rendah dalam hal kondisi faktor; kondisi permintaan; industri pendukung dan terkait; strategi, struktur, dan kompetisi yang merupakan komponen dari model berlian Porter.
\end{abstract}

Kata Kunci: persaingan, produk tekstil, keunggulan komparatif, produk ekspor dinamika, model berlian Porter

\section{How to Cite:}

Prasetyani, D., Abidin, A. Z., Purusa, N. A., \& Sandra, F. A. (2020). The Prospects and The Competitiveness of Textile Commodities and Indonesian Textile Product in the Global Market. Etikonomi: Jurnal Ekonomi, 19(1), 1 - 18. https://doi.org/10.15408/etk.v19i1.12886. 


\section{Introduction}

The Textile Industry and Textile Products (TPT) has become one of the national flagship industries as contained in the 2015-2035 National Industrial Development Plan (RIPIN) Master Plan document. This flagship industry is a priority industry that plays a role as a prime mover of the future economy. The positive performance of this industry can see from the total production of textiles, which consistently grew from 2013 to 2017. This study used data from 2013-2017 due to data availability issues. Based on constant prices in 2010, total textile production continued to increase from Rp 116.56 trillion in 2012 to Rp 150, 43 Trillion in 2017 with an average annual growth of 1.25 percent (Indonesian Textile Association, 2018). The focus is on developing export areas. This study aims to find new export areas. Similar to the other research is Quality Function Deployment (QFD), which is a quality development methodology that demonstrates the precise customer needs into technical solutions. The purpose of the QFD methodology is to connect customer requirements and technical solutions. This method supports to define the customer and market-business expectations by a group of tools-house of quality and combined (Erdil, 2019).

Sabonien et al. (2014) analyzed the exogenous factors of low-tech industries' competitiveness in Lithuania. They found that the importance of these factors has been examined at the example of Lithuanian textile and wearing apparel sectors with the help of an expert survey. On the other hand, Shen \& Li (2019) examine the impact of clean technology adoption on the textile supply chains with environmental taxes. The adoption of green technology can enhance product greenness and reduce unit production costs. This study finds that optimal greenness levels are increasing in environmental taxes, and when the coefficient of competition is higher, the greenness level is also higher.

In the latest study, Zhao \& Lin (2020) demonstrate positive feedback between foreign trade and energy efficiency in the textile industry, with imports impacting energy efficiency more than doing exports. Another empirical study in China from Guan et al. (2018) revealed that the country has a large textile industry base and still significantly contribute to China's economic growth since the old-time up to these days. However, there are still some obstacles, such as increased domestic production costs, uncertainty in both domestic and international markets, and trade barriers. This study revealed that labor, demand conditions, strategies, the structure of the textile industry, policies, and opportunities have a positive impact on the export value and the ratio of the export of Chinese textile to world exports. In contrast, raw materials and capital have negative impacts.

Meanwhile, studies conducted by Parrish et al. (2008) show that the United States TPT industry can remain competitive in global competition. This research proves that US textile companies encourage innovation in the supply chain from suppliers and consumers. Also, successful strategies for creating excellence for United States products compared to products from other countries include research and development, marketing, and services. The TPT industry has always been the top three in contributing to the value of Indonesia's non-oil exports. Even from 2012 to 2016, the textile industry was the second rank in its contribution to the value of Indonesia's non-oil exports, while the first rank is the food industry whose export value is quite far from the value of other commodity exports. (See Figure 1). 
Figure 1. Five Greatest Indonesian Non-Oil and Gas Industries Exports Values between 2011-2017

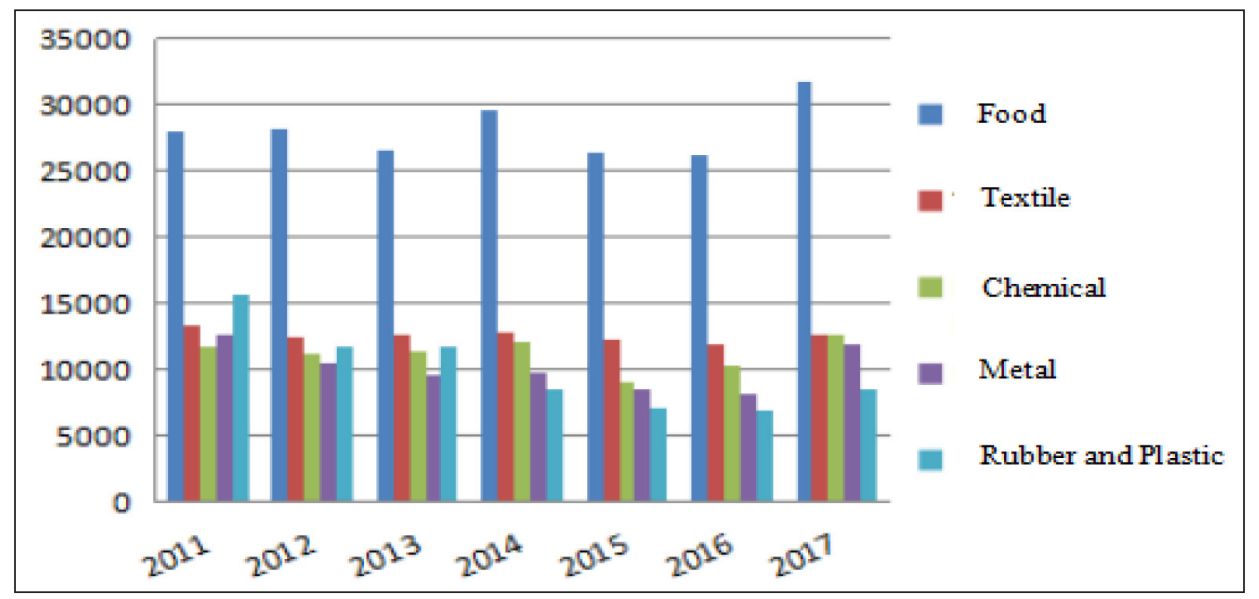

Source: Central Bureau of Statistics (2019)

Figure 1 shows that the export commodities of Indonesian textile Products have not gotten significant development, although the trade balance is still a surplus every year. Indonesia's TPT commodity share is only 1.27 percent of the total world textile exports, and Indonesia ranks 20th as an exporter of textile Products (World Integrated Trade Solution, 2019). The regions that are the main export destinations for Indonesian TPT commodities are the United States of America at 32.34 percent, followed by the European Union at 14.97 percent and Japan at 10.08 percent.

While in the ASEAN region, Indonesia became the most significant textile exporting country until 2007. A year later, Vietnam outperformed the export value of Indonesian textile and became more decreased in the following years, as can be seen in Figure 2. This situation is to be the impact of reaching an agreement between the Vietnamese state and the World Trade Organization (WTO) in 2007 that was able to open new export markets with low charge (Hamid \& Aslam, 2017). The competitiveness of Indonesian workers in the TPT industry is also lower compared to Vietnam. Problems that trigger the low competitiveness of Indonesian workers include occupational health and safety, training, fewer working hours, timeliness of payment, and harassment of workers (Wahyuni \& Boeditomo, 2015).

Figure 2. The Indonesian and Vietnamese textile Products Export Values (in Thousand US Dollars)

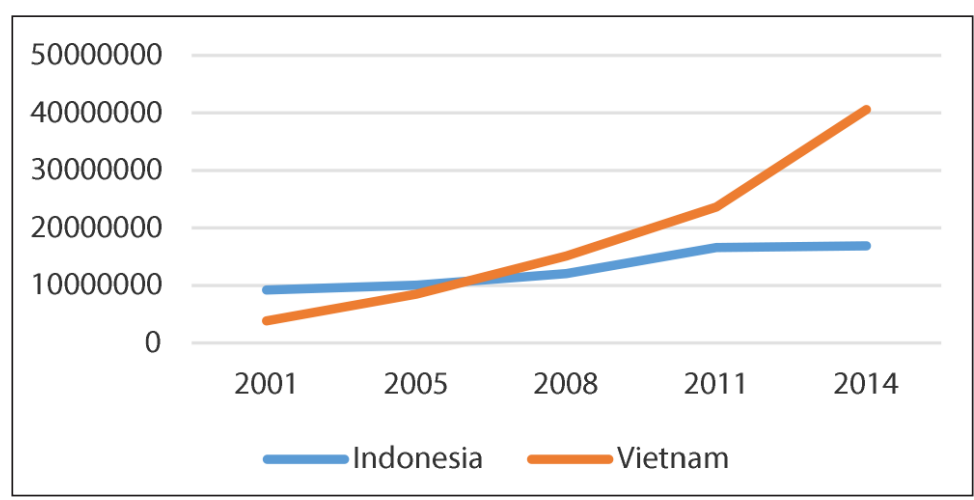

Source: World Integrated Trade Solution (2019) 
The data is a reflection of the textile industry in Indonesia, where many factors trigger competitiveness itself. Based on these conditions, researchers are encouraged to make a more profound identification of the competitiveness of textile commodities and textile products, which are also one of Indonesia's leading non-oil and gas export commodities. This research will test two things, product competitiveness in the global market and industry competitiveness. The competitiveness of Indonesian TPT products or commodities in the global market will be analyzed using Revealed Comparative Advantage (RCA) and Export Product Dynamics (EPD) so that the research also reveals the prospects of countries becoming new export markets for Indonesian TPT commodities. Competitiveness can interpret as the ability of a commodity to be able to enter foreign markets and survive in the dynamics of the market.

In line with this, competitive products are certain products that are always in demand. A competitive advantage, which is a differentiator from the others, has been modified and classified into a natural advantage and acquired advantage (Susilo, 2013). The competitiveness can also show from the availability of cheap and abundant labor, abundant natural resource ownership, the influence of government policies, and differences in management practices (Porter, 1998). In the international trade perspective, when a country does not have an absolute advantage, they can still do production by considering the comparative advantage they have so it could create competitiveness. Heckscher-Ohlin's theory emphasizes that laborintensive countries must focus on production that relies on labor-intensive while countries with higher capital intensity focus on the production of capital-intensive goods (Salvatore, 2014). Indirectly the mechanism is also related to the competitiveness of a country. The performance of the industry also influences competitiveness.

The analysis of the competitiveness of the TPT industry uses Porter's Diamond model with a case study of textile companies in the Solo Raya region. It is because the Solo Raya TPT industries are considered a barometer of the national TPT industry. Also, there is the largest TPT company in Southeast Asia in this region, such as PT Sri Rejeki Isman, which is consistent with integrated production from raw material processing to the garment, then it can be used as a benchmark. Besides, in 2015, the government also started to develop the textile industry in the region by diverting a large part of the TPT industry's investment, which previously was 40 percent spread in West Java Province. The textile products investment start in 2015, which is amounted to Rp 4.6 trillion with 188 projects and projected to absorb a workforce of 79,131 people. Based on all the previous studies above, it can show that most of the research discussed the factors; either endogenous or exogenous ones, behind market competitiveness for textile industries in some countries. The research gap between these studies will be the lack of exploration within the competitiveness scope itself. Especially since the previous studies only told us about the China and US textile markets, and not the South East Asian areas, including Indonesia as an emerging country for textile commodities exports.

Therefore, this study implies exploring the effectiveness of Indonesian textile products and its' prospects in the global market. The contribution within the study will be about identifying the new potential markets for Indonesian textile commodities in certain countries across the globe. Such contribution will boost the textile exports as well as the Indonesian economy in general. If such possibilities may happen shortly, then Indonesia may have 
the chance to become one of the biggest textile exporting country in the world. Thus, this research has the purpose of identifying both the prospects, competitiveness, and potential new markets for Indonesian textile commodities in the upcoming future.

\section{Methods}

\section{Revealed Comparative Advantage (RCA)}

This method is using to measure the competitiveness and superiority of Indonesian textile commodities and textile products in the global market. According to Tambunan (2008), every country that has a comparative advantage over the production and goods export is a country with a higher total export percentage than the share of the same goods in total world exports. To see the competitiveness of Indonesian TPT products (RCA and EPD) in the global market using secondary data from 2015-2017. There are 76 countries analyzed, and these countries have trade agreements and are in the stage of filing with Indonesia. The data obtained from the World Integrated Trade Solution.

The general formula used in the Revealed Comparative Advantage (RCA) method is as follows (Hadzhiev, 2014):

$$
\mathrm{RCA}=\left(\mathrm{X}_{\mathrm{ij}} / \mathrm{X}_{\mathrm{t}}\right) /\left(\mathrm{W}_{\mathrm{ij}} / \mathrm{W}_{\mathrm{t}}\right)
$$

Where: RCA is the level of competitiveness of Indonesian Garment in the importing country; $\mathrm{X}_{\mathrm{ij}}$ is the Indonesian Garment exports value in the importing country; $\mathrm{X}_{\mathrm{t}}$ is the total export value of Indonesian products in the importing country; $\mathrm{NW}_{\mathrm{ij}}$ is the world Garment exports value in the importing country; $\mathrm{W}_{\mathrm{t}}$ is the total export value of world products in the importing country

The interpretation of the RCA index is based on the classification that has been described by Hinloopen $\&$ van Marrewijk (2008). First, Class a that has a values range from 0 - 1 . Covers all products from countries where competitiveness is unknown. Second, Class $\mathrm{b}$, the values range in the interval of $1-2$. Having weak competitiveness. Third, Class $\mathrm{c}$, the difference in RCA value in the interval of 2 - 4. Having medium competitiveness. Fourth, Class $\mathrm{d}$, the RCA Value $>4$, it means having strong competitiveness.

\section{Export Product Dynamics (EPD)}

EPD (Export Product Dynamics) analysis functions to identify the competitiveness of a product and to find out the product performance in dynamic or undynamic conditions (Zuhdi \& Suharno, 2015). According to Esterhuizen (2006), if a product has an export growth value that exceeds the average export value continuously, then the product is likely to become the primary source of income for a country. These products can compete in the international market level.

Based on Figure 3, the Export Product Dynamics method consists of four categories that show the attractiveness and strength of the product. First, rising star. This category shows that a country is gaining an additional share of the fast-growing textile market. Second, lost opportunity. This category comes with the condition when a dynamically moving TPT has a decreased market share, where the TPT supply in the world is higher than the supply of 
Indonesian TPT. Third, a falling star. This category is almost the same as the lost opportunity category. It means that this category shows the TPT market share, which continues to increase. Fourth, retreat. This category shows a setback from TPT. Generally, this category provides a positive trend if the movement away from a stagnant position towards a dynamic condition.

Figure 3. Market Attractiveness and Business Strength in EPD

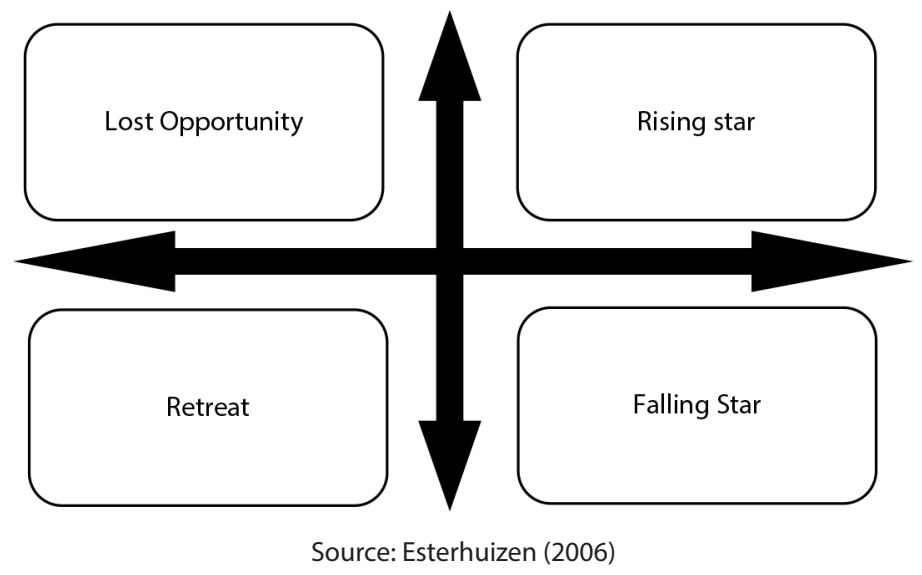

The formula used in the Export Product Dynamics method. First, to determine the growth of business strength (X-axis), we use the following equation:

$$
X-\operatorname{axis}=\frac{\left(\frac{x_{i j}}{W_{i j}}\right) t \times 100 \%-\sum_{t=1}^{t}\left(\frac{x_{i j}}{W_{i j}}\right) t-1 \times 100 \%}{T}
$$

Second, to determine the growth of market attraction (Y-axis), we use the following equation:

$$
Y-\operatorname{axis}=\frac{\left(\frac{X_{t}}{W_{t}}\right) t \times 100 \%-\sum_{t=1}^{t}\left(\frac{X_{t}}{W_{t}}\right) t-1 \times 100 \%}{T}
$$

Where: $\mathrm{X}_{\mathrm{ij}}$ is garment export value to the importing country; $\mathrm{W}_{\mathrm{ij}}$ is the world's garment exports value to the importing country; $\mathrm{X}_{\mathrm{t}}$ is the total export value of Indonesian products in the importing country; $\mathrm{W}_{\mathrm{t}}$ is the total of world export products to the importing country; $\mathrm{T}$ is Number of years of analysis.

\section{Results and Discussion}

The competitiveness of Indonesian TPT products is analyzed using the Revealed Comparative Advantage (RCA), which specifically looks at the competitiveness of Indonesian TPT products in each export destination country. The RCA was then re-developed with Symmetric Revealed Comparative Advantage (RSCA) to see whether competitiveness is an advantage or disadvantage. Also, the Export Product Dynamics (EPD) analysis tool is using to see the market position of Indonesian TPT Products in each of the Export destination countries.

The export destination countries analyzed in this study are limited to countries that have a trade agreement or are in the planning stage with Indonesia. Besides, the trade agreement here does not see whether the TPT product is a commodity in the agreement. Based on these groupings, there are 76 countries analyzed in this discussion. Besides, all of these countries 
consist of 10 countries that constitute the majority of the Indonesian TPT product export market or the existing export market of Indonesian TPT products, and 66 other countries are analyzed to see the potential for developing new export markets.

\section{The Commodities Competitiveness of Indonesian textile Product in the Existing Export Markets}

The Existing Export Markets of Indonesian TPT Products in this study are ten countries with the most significant percentage of export value of Indonesian TPT Products. These countries are the USA, Japan, China, South Korea, Germany, Turkey, United Arab Emirates, Malaysia, Belgium, and the United Kingdom. The total exports of Indonesian textile products to these countries reached 70.98 percent of the total exports of Indonesian textile products.

Figure 4. Indonesian TPT Product Export Destinations

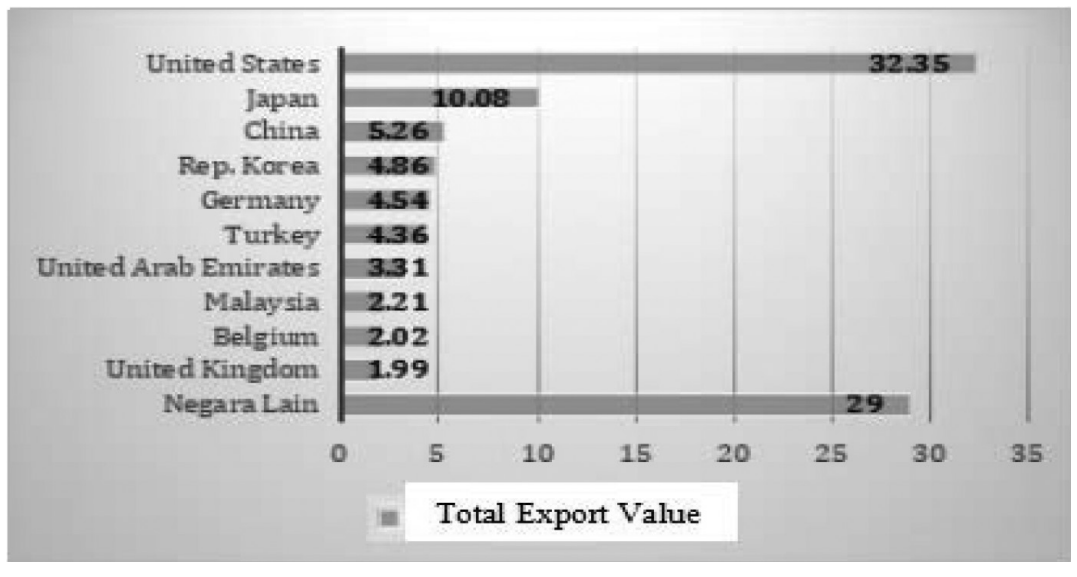

Source: Data Processed

Figure 4 shows the export destinations for Indonesian TPT products based on the highest percentages of export values. From the top 10 country destinations, the United States has the most significant export value percentages, with up to $32.35 \%$ from the whole Indonesian TPT products export. Japan becomes the second with $10.08 \%$, and China becomes the third with $5.26 \%$ export values percentages for Indonesian TPT products. The rest of the destinations such as the Korean Republic, Germany, Turkey, United Arab Emirates, Malaysia, Belgium, and the United Kingdom have shared below 5\% for these commodities export. The other $29 \%$ belong to other countries that are not the leading destinations for Indonesian TPT products.

Based on the results of the analysis of RCA, RCA, and EPD from the ten countries that became the destination of Indonesian exports. Table 1 shows that there is a dynamic movement in the potential competitiveness of Indonesian TPT commodities. In Belgium, Turkey, and the United Arab Emirates, Indonesian textile products have very high competitiveness compared to textile products from other exporting countries. Also, Indonesian textile products dominate the textile market in these three countries. 
Dwi Prasetyani. The Prospect and The Competitiveness of Textile Commodities

Table 1. The results of the RCA and EPD values of Indonesian TPT products in 10 main destination countries for the 2014-2016 period

\begin{tabular}{cllcc}
\hline No. & \multicolumn{1}{c}{ Country } & \multicolumn{1}{c}{ RCA Classification (2016) } & RSCA Classification & EPD \\
\hline 1 & Belgium & Strong Comparative Advantage & Advantage & Rising Star \\
2 & Turkey & Strong Comparative Advantage & Advantage & Rising Star \\
3 & Uni Emirat Arab & Strong Comparative Advantage & Advantage & Rising Star \\
4 & USA & Strong Comparative Advantage & Advantage & Lost Opportunity \\
5 & Germany & Medium Comparative Advantage & Advantage & Lost Opportunity \\
6 & South Korea & Medium Comparative Advantage & Advantage & Lost Opportunity \\
7 & United Kingdom & Medium Comparative Advantage & Advantage & Lost Opportunity \\
8 & Japan & Weak Comparative Advantage & Advantage & Rising Star \\
9 & Tiongkok & Weak Comparative Advantage & Advantage & Rising Star \\
10 & Malaysia & Weak Comparative Advantage & Advantage & Lost Opportunity \\
\hline
\end{tabular}

Source: Data Processed

In the USA, Indonesian textile products have very high competitiveness compared to textile products from other exporting countries. However, the relative level of production volume and the volume of Indonesian textile products entering the USA is lower than the growth in demand for textile products in the USA. In Germany, South Korea, and the United Kingdom, Indonesian textile products have not been able to excel in competitiveness. Besides, the growth in exports of Indonesian textile products is still lagging when compared to the growth in demand for textile products in the three countries.

For Japan and China, although Indonesian TPT products dominate the markets in both countries, the competitiveness of Indonesian TPT products is in the weak category. It needs to consider because the dominant position of the Indonesian TPT product market in both countries can shift when other exporting countries have TPT products with better competitiveness. The export condition of Indonesian textile products to Malaysia is in a vulnerable position. The competitiveness of Indonesian textile products in Malaysia is in a weak position. This fact was reinforced by the weaker growth rate of Indonesia's textile products exports compared to the growth in demand for textile products in the country.

\section{The New Export Markets for Textile Commodities and Indonesian Textile Products}

The analysis of new export markets for Indonesian TPT commodities in this study based on the Focus Group Discussion (FGD) result with some Indonesian Textile Companies. These are additional countries to the ten central export destination countries for Indonesian TPT products mentioned before. The development of new export destinations for Indonesian TPT products focuses on countries where Indonesian TPT products have strong competitiveness, as indicated by the results of RCA (Strong Comparative Advantage), RSCA (Advantage), and EPD in the Rising Star position. Other export destination countries do not mean that they do not have reasonable prospects going forward, but the focus of the study is to look at new 
export destination countries, which are a priority to be developed and can increase the value of Indonesia's TPT commodity exports. Based on the FGD results, the new export markets for Indonesia’s TPT commodities are in Austria, Canada, Finland, Norway, Portugal, Qatar, and Sweden.

Data from the World Integrated Trade Solution (WITS) showed contributing indicators regarding these new export destination countries for Indonesian TPT products. Based on the GDP, almost all these countries showed an increasing amount of GDP from 2013-2017. Most of these countries also have high rates of inflation, especially around the year 2016-2017, which happened in Austria, Canada, Finland, Portugal, and Sweden. The rising GDP may trigger higher consumption within these countries, while the high inflation rates may become a benefit for import products such as Indonesian TPT products. These economic situations are blessings so that Indonesia may reach new export markets for textile commodities. Only Qatar and Norway have deflation until the year 2017 (WITS, 2019). There are other data such as the total export values for Indonesian textile products to these countries, both the RCA and EPD calculation, also data about population structures and product segmentations for each country. Based on the FGD with the Indonesian Textile Association (Asosiasi Pertekstilan Indonesia/ API), the additional data support the discussion that these countries can be the new export destinations for Indonesian textile products soon.

Total export values for Indonesian textile products showed excellent measurements for these countries. Canada has the most significant percentages for exporting these Indonesian commodities with $2.26 \%$ import values over the whole textile import values in Canada around 2016, while Qatar becomes the second with 2.02\% import shares over their whole textile imports in the same year. The rest of the countries only have import shares for Indonesian textile products, around 1\% or even below. Finland has 1.13\% import shares, Austria and Portugal with $1.1 \%$ import shares, Norway with $1.04 \%$ and Sweden with the lowest import shares between these countries, with $0.72 \%$ import shares for Indonesian textile products over their whole textile import products in 2016 (API, 2018).

Age structures within these new export destination countries showed that most of the countries' population majority is within the age span around 0-64 years old, only in Canada and Portugal, where the number of the higher population is not in such category. Canada has a higher number of the population between 0-14 years old. Therefore the textile products will be segmented to baby clothing and fashion products. While for Portugal, the majority of the population are people who are $>65$ years old so that the textile products will segment for adults fashion. On the other hand, the rest of the countries with a significant population within the age of 0-64 years old will have product segmentation for both baby clothing and adults fashion products. Based on all these data, the RCA methods and EPD calculations made. The RCA method showed that all these new export destination countries for Indonesian textile products have definite comparative advantages. The EPD calculation also showed that these whole countries categorize as "rising star" for the new Indonesian textile export market. These methods show that Indonesian textile products can compete in all these countries' textile markets, due to high demand in each country and the export growth for these commodities in Indonesia. 


\section{The Analysis of the Competitiveness of the Textile Industry and Textile Products}

Industry in a country will have competitiveness if the company can be competitive. A country's competitiveness is also determined by the ability of the industry to innovate, which can include technical improvement of the production process and increasing its capacity. Companies gain competitiveness because of pressures and challenges. The company receives benefits from competition in the domestic market, aggressive domestic suppliers, and local markets that have high demand. Differences in cultural values, economic structure, institutions, and history all contribute to success in competition.

Porter (1998) revealed the new ways that usually obtain from changes in the industrial structure. Several things can underlie innovation and shift the competitive advantage. First, the emergence of new technology. Second, shifting consumer needs. Third, the new industrial segments emergence that includes new ways to produce certain goods or new ways to reach groups certainly. Fourth, changes in production costs such as raw materials, transportation, communication, and labor. Fifth, changes in government regulations that can provide a stimulus for industries to innovate and expand marketing or instead provide obstacles for industries to develop.

The discussion in this section focuses on the competitiveness of the Indonesian TPT industry with case studies in the Solo Raya region and using the Porter's Diamond Model. Porter (1998) proposes the Diamond Model (DM), which consists of four main determinants that determine competitiveness, namely factor conditions; demand conditions; supporting industries and related industries; company strategy, structure, and competition. Besides, there are two additional determinants of opportunity or opportunity and government support.

The first factor based on the diamond's model is condition factors. The condition of production factors in the Indonesian textile industry described in this study consisted of raw materials, human resources, machinery, and logistics. The raw materials from this industry are: First, Cotton Fiber. Domestic cotton production is only able to meet the national cotton needs of $0.1-2.3 \%$, so that the dependence of cotton imports on the national textile industry is high, which is more than $97 \%$. According to data from the agriculture ministry, the volume of cotton import growth in 1980-2014 fluctuated but tended to rise with an average growth of $7.2 \%$ per year. Indonesia ranks fifth in the world as a cotton importer, whereas the textile industry in the upstream sector in Solo Raya uses 100\% cotton imports. The golden period of national cotton production, in 2002-2011, ended along with the decline in the government's concern for cotton and the increasing existence of other plantations such as palm oil, sugar cane, and rubber. The success of cotton production at that time also consider artificial because cotton cultivation, as a central government program, did not have a comparative advantage (Hermawan, 2018).

The second raw material is synthetic fiber. There are two types of synthetic fiber, such as rayon fiber and polyester. Three companies in Indonesia produce rayon fiber, and two companies are types of foreign investment (PMA) such as Austria and India. The only national company that has produced this fiber is PT Sritex, which develops products from eucalyptus plants, and only leaves utilize. For the polyester, domestic supply is insufficient 
to meet their needs, so if there is an expensive price. This condition is also almost the same as polyester imports from abroad because of the additional import duty as a result of antidumping PSF (Polyester Staple Fiber) proposed by APSyFI (Indonesian Fiber and Filament Yarn Manufacturers Association) since 2010.

The third raw material is fabric. Garment companies or those in the downstream industries always have a shortage of domestic raw materials. On the other hand, the demand for garments is increasing, and this industry is dependent on imported fabrics. Domestic supply is insufficient for the needs of the national apparel industry. Also, many garment companies use the by order system, where the raw materials used to meet buyer requirements, mostly imported fabrics. The buyer's request cannot be fulfilled if it must use fabrics produced in Indonesia, so the import of fabrics becomes a way to fulfill them.

The second condition factor is human resources. In the TPT industry, more human resources need in the downstream sector, namely garment. Garment companies need more workers than companies in the upstream and intermediate sectors. Meanwhile, the condition of garment companies in Solo Raya is still challenging to get workers, especially those who have skills as sewing operators. The sewing operator owned by the company in Solo Raya also considers having low productivity and high turnover.

The third condition factor is a machine. The textile industry has capital-intensive characteristics, one of which is because of the extensive use of machines for production. Most of the machinery used in the textile industry is old, and 80 percent is over 20 years old. The cost of maintaining these machines is also high, so that the competitiveness of textile production machines is relatively low.

The final condition factor is logistics. Logistics relates to the costs incurred by producers to export products to export destination countries. One of the obligations owed by the producer is "port clearance" or obligation that must fulfill to the terminal operator at the port where the goods stop. These obligations are related to THC (Terminal Handling Charge) and moving risk costs. The National Textile Dialogue shows that the costs of Indonesia's ports are high compared to other Asian countries such as Thailand, Malaysia, Vietnam, and Bangladesh (See Table 2).

Table 2. THC costs on ports, 2018

\begin{tabular}{ccc}
\hline Country & \multicolumn{2}{c}{ (USD/Container) } \\
& 20 Feet & 40 Feet \\
\hline Ho Chi Minh, Vietnam & 46 & 135 \\
Chittagong, Bangladesh & 49 & 75 \\
Bangkok, Thailand & 60 & 95 \\
North Port, Malaysia & 64 & 97 \\
Tanjung Priok, Indonesia & 95 & 145 \\
\hline
\end{tabular}

Source: Dialog Tekstil Nasional, 2018 
The second factor from the diamond's model is the demand condition. The textile industry sector that has the highest export value is the garment industry. However, the realization of garment exports nationally has decreased from 2013 to 2016, with an average decline in exports of 1\% annually. However, in 2017 there was an increase in the value of garment exports. It also happened to exports of Solo Raya garment companies that experienced a decline in export volumes from 2013-2017. Although the value is still volatile, in 2016 and 2017 shows a decline from the previous year (See Table 3).

Table 3. Value of Garment Exports in Solo Raya 2013-2017

\begin{tabular}{|c|c|c|}
\hline \multirow{2}{*}{ Year } & \multicolumn{2}{|c|}{ Realization } \\
\hline & Volume (Ton) & Worth (Billion Rp) \\
\hline 2013 & $8,023,793$ & 600.84 \\
\hline 2014 & $7,687,960$ & 609.40 \\
\hline 2015 & $7,572,834$ & 751.13 \\
\hline 2016 & $6,488,897$ & 656.63 \\
\hline 2017 & $5,651,043$ & 556.08 \\
\hline
\end{tabular}

Source: Data Processed

The garment industry in Solo Raya receives more requests from abroad because it still has cheap labor so that product prices can still compete abroad. It can say that the product produced is also a textile product with minimal innovation. If viewed from Porter's Diamond approach, the company will gain a competitive advantage if the demand from buyers is the most sophisticated or cutting-edge product. Meanwhile, based on the FGD with textile product businesses, the products produced by Indonesia are classified as less innovative or only tend to meet the demand for textile products in general. While other companies globally have developed textile products for building materials and road-building materials, even in Canada, aircraft have developed with textile raw materials. The condition of textile companies in Indonesia is still helped by the presence of PT Sritex, which can develop its products such as military uniforms, waterproof, insect repellent, non-flammable, anti-stain, anti-wrinkle, anti-infra red, clothing from the lightest to the heaviest, and breathable materials.

The third determining factor in the analysis of industrial competitiveness is the presence of competitive suppliers or related industries in the country. Competitive suppliers on a national and international scale will provide advantages for downstream industries. These suppliers can provide low input prices and short delivery times so that efficiency in the downstream industry can create. This condition also relates to the proximity of the supplier's location to downstream industries.

The condition of the TPT industry in Solo Raya is not interrelating between upstream, between, and downstream, it is demonstrated by the by order system run by the majority of garment companies / downstream industries, wherein the buyer determines the raw material used and the majority uses the material from abroad. This condition has an impact on the upstream industry and among those who lack market guarantees. So the upstream and 
intermediate industries on the local scale find it challenging to increase their capacity and quality.

The fourth determining factor for the competitiveness of the national TPT industry is the variety of strategies, objectives, and corporate organizations in the context of domestic competition. National competitiveness can create by good competition among companies in an industry where it can produce a competitive source of power at the national level. Intense domestic competition not only creates national industrial excellence but also encourages companies to improvise and innovate.

In general, the condition of TPT companies in Solo Raya does not occur direct competition between companies, because the production specifications carried out by each company form their market share. Besides, the by-order system by the majority of garment companies in Solo Raya also creates its market share. In general, companies that serve orders from buyers only sell sewing services that require efficient production costs, especially labor. Competition in companies with such business models occurs in the supply of labor. Garment companies in Solo Raya have struggled to find workers in 2 years.

This condition is revealed by PT Dan Liris and Sritex that is a large-scale integrated textile company. The two companies are not competing with each other because they have different focus even though they both have the same line of business, namely spinning, weaving, finishing, printing, and garment. The garment division at PT Dan Liris consists of Ifrata Retail Indo that includes Bateeq (premium batik for the youth segment) and Ambassador Garmindo, to work on uniforms for companies such as Kalbe Farma, Kimia Farma, and Unilever. In contrast, the garment division of PT Sritex has specifications on products for waterproof, insect repellent, stain-resistant, anti-wrinkle, anti-infrared, and nonflammable clothing.

The fifth determining factor for competitiveness is chances or opportunity. The opportunity referred to in this discussion, is anything that is beyond the control of companies and governments. The opportunity can have a good or bad impact on the performance of the competitiveness of the textile industries and textile product. Current conditions, the United States government is evaluating about 124 imported products from Indonesia, including textiles, plywood, cotton, and some fishery products such as shrimp and crabs. The evaluation carried out to determine what products are still eligible to receive the Generalized System of Preference (GSP). GSP is a trade policy of a country that provides import duty cuts. This GSP is a unilateral trade policy (generally unilateral) developed countries to help the economy of developing countries but is not binding for both donor and recipient countries. The President of the United States will sign recommendations from November 2018 until early 2019. If it no longer gets the preference, Indonesian TPT products will have difficulty entering the United States market and can reduce exports to that country.

While Indonesia's most significant textile product export share is currently exporting, based on data from WITS, the destination of Indonesian textile product exports to the United States is 32.35 percent of Indonesia's total textile product exports (second place in Japan, with an export share of 10.08 percent). With current conditions, the generalized system of 
preferences in Indonesian products, including textiles and textile products, which are being considered by the United States government, can be the key to increasing or reducing the potential for Indonesian textile product exports.

The current United States Government that has an orientation to reduce the trade balance deficit has an impact on strengthening the value of the United States Dollar (US \$). This condition was reinforced by the policy of the Central Bank of the United States (The Fed) to raise interest rates to maintain inflation in the country. This further strengthens the value of the United States currency. Of course, the increasing value of US \$ poses a threat to Indonesia, especially in the Textile Industry and Textile Products, which still rely on imported raw materials, namely imports of cotton and finished fabrics. The increase in the value of the United States dollar can increase the price of these raw materials and will affect production costs and the competitiveness of Indonesian textiles and textile products.

The final factor is the government, in its efforts to support the development of the domestic textile products industry and increase exports, carried out through policy instruments and trade diplomacy with other countries. However, at this time, traders are also permitted to import through a bonded logistics center (PLB). In the previous regulation, Regulation of the Minister of Trade No. 85 of 2016 concerning Integrated Services for Trade, only producers were allowed to import. This condition has an impact on the flood of imported products, especially fabrics, which have continued to increase in the last five years, and put pressure on some fiber and yarn companies, and some have even closed down. However, for the needs of fiber and yarn other than cotton can still be met from within the country. Current conditions, although the supply of raw materials can supply domestically, imported products continue to enter, and this is pressing the industry. Indeed, in the end, it is easier for garments because they still need-imported fabrics for production.

The analysis of the competitiveness of Indonesian TPT products uses Revealed Comparative Advantage (RCA) and then developed with Symmetric Revealed Comparative Advantage (RSCA) to see whether competitiveness is an advantage or disadvantage. The clothing or garments industry has developed rapidly during the past few decades. The industry has contributed to the economic growth of many nations, both developed and developing countries. This industry has very much regulated by many bilateral agreements such as MultiFiber Arrangement (MFA), a quota arrangement made by the importing countries (Shihab \& Jain, 2004).

Kuncoro (2013) explains the industrialization and sectoral changes in Indonesia since 1968. In terms of trade, TPT products always in the top ten of Indonesia's non-oil exports. Major clusters in the Indonesian TPT are concentrated geographically in 5 provinces in Java Island. In particular, this research evaluates challenges facing Indonesia's TPT industry in the face of new competitions from abroad. A particular emphasis puts on assessing Indonesia's competitiveness relative to its main competitor in the industry. In the future, it predicts that the consumption of TPT will be increasing each year, in line with the world 
population growth and the demand-driven by lifestyle. Indonesia's garment, textiles, and footwear sector continue to be a significant contributor to the country's manufacturing gross value added. However, despite buoyant investment and diversifying export partners, output has been slowing. The industry's declining economic performance has driven by the sub-industry of textiles and wearing apparel, with improvements in footwear and leather products.

Besides, the Export Product Dynamics (EPD) analysis tool used to see the market position of Indonesian TPT Products in each Export destination country. This paper explains the potential of Indonesia's textile trade relations and based on all countries that have trade relations with Indonesia. From these countries, we grouped and found 10 countries with the best potential for the textile trade. In 10 export destination countries such as Belgium, Turkey, United Arab Emirates, USA, Germany, South Korea, United Kingdom, Japan, China, and Malaysia, the RSCA classification value shows that the value of exports is profitable. With rising star ratings from the profit level are Belgium, Turkey, the United Arab Emirates, Japan, and China, whereas the lost opportunity rankings are USA, Germany, South Korea, United Kingdom, and Malaysia.

In this case, the government established a bonded logistics center to increase the export value of textile products and facilitate the procurement of imported raw materials and support the by-order system that is mostly used by garment companies. Also, the import duty suspension facility can obtain from the companies that not included in the bonded zone through the KITE facility (Ease of Import for Export Purpose). Besides, a proactive attitude from the government is needed to open new markets abroad. The Indonesian Trade Promotion Center (ITPC), that is a government-owned non-profit organization under the supervision of the Directorate General of Indonesian National Export Development, is expected to open new export markets for textiles and textile products.

Textile is a national mainstay industry, so the government needs a commitment to pay more attention to this sector. In this case, the government can do several actions such as: First, clarify the rules around regulation, facilitation, funding, and assistance. Second, providing incentives such as tax holidays to increase the rate of investment in the Textile sector. Third, more aggressive international trade diplomacy so that international trade agreement schemes, especially with potential countries, can be implemented immediately. Besides that, the textile industry needs an effective solution to support digital transformation (Ku et al., 2020), because the innovation will have a more significant influence on the process in the textile industry (Padilha \& Gomes, 2016).

\section{Conclusion}

Indonesian TPT commodities in some of the central export destination countries have low competitiveness, and these commodities have a lost opportunity category that indicates that there is a decline in the market share of Indonesian products. This condition occurred in the United States, Germany, South Korea, United Kingdom, and Malaysia. Although the RCA classification still shows strong competitiveness for these commodities. Furthermore, 
based on the EPD analysis, there are several new destination countries aside from the ten central export destination countries for Indonesian textiles and textile products. Indonesian textile products have strong competitiveness and dominate the market in Austria, Canada, Finland, Norway, Portugal, Qatar, and Sweden. While the Industrial competitiveness analyzed using Porter's Diamond model shows that the Indonesian textile Products industry has low competitiveness. In terms of production factors, most of the raw materials use cotton fibers, and imported fabrics, difficulties in getting sewing operators in garment companies, machine conditions 80 percent are over 20 years, and logistics costs in Indonesia are still more expensive than Vietnam, Bangladesh, Thailand, and Malaysia.

The majority of Indonesian TPT product demand is products with minimal innovation, whereas according to Porter (1998), the competitiveness of the industry can be said to be high if the demand is sophisticated or cutting-edge products. Also, this condition compounded by the phenomenon of the fragmentation of the textile industry in which the majority of the garment industry uses a by order system whose raw materials are obtained from abroad to meet buyer requirements. So that upstream industries lack market guarantees, and it is challenging to develop their quality and capacity. The Strategy, Structure, and Competition aspects also show that there is no direct competition, thereby reducing the competitiveness of the industry itself. Each company has its market share and targets despite having the same line of business. Based on current conditions, there are still opportunities for Indonesia to increase its exports because there are several developed countries where Indonesian TPT commodities are classified as rising stars and have strong competitiveness. However, global economic conditions accompanied by high uncertainty tend to be unfavorable for Indonesia. Government support also still does not show a solution that leads to solving the fragmentation of the Indonesian textile industry.

\section{References}

Erdil, A. (2019). An Evaluation on Lifecycle of Products in Textile Industry of Turkey through Quality Function Deployment and Pareto Analysis. Procedia Computer Science, 158, 735-744. https://doi.org/10.1016/j.procs.2019.09.109.

Esterhuizen, D. (2006). Measuring and Analyzing Competitiveness in the Agribusiness Sector: Methodological and Analytical Framework. (Unpublished Dissertation). Pretoria: University of Pretoria.

Guan, Z., Xu, Y., Jiang, H., \& Jiang, G. (2018). International Competitiveness of Chinese Textile and Clothing Industry: a Diamond Model Approach. Journal of Chinese Economic and Foreign Trade Studies, 12(1), 2-19. https://doi.org/10.1108/ JCEFTS-01-2018-0003.

Hadzhiev, V. (2014). Overall Revealed Comparative Advantages. Eurasian Journal of Economics and Finance, 2(1), 47-53.

Hamid, M. F., \& Aslam, M. (2017). Intra-regional Trade Effects of ASEAN Free Trade Area in the Textile and Clothing Industry. Journal of Economic Integration, 32(3), 660-688. https://doi.org/10.11130/jei.2017.32.3.660. 
Hermawan, I. (2018). Paradigma Pengelolaan Industri TPT: Perspektif Swasembada Kapas vs Kondisi Berbasis Impor (The TPT Industry Management Paradigm: Cotton Self-Sufficiency Perspective vs Import Based Conditions.). In Rusastra, I. W. Pengembangan Industri Tekstil Nasional: Kebijakan Inovasi dan Pengelolaan Menuju Peningkatan Daya Saing (Development of the National Textile Industry: Innovation and Management Policies Towards Increased Competitiveness). Jakarta: Yayasan Pustaka Obor Indonesia.

Hinloopen, J., \& Van Marrewijk, C. (2008). Empirical relevance of the Hillman condition for revealed comparative advantage: 10 stylized facts. Applied Economics, 40(18), 23132328. https://doi.org/10.1080/00036840600949488.

Ku, C-C., Chien, C-F., \& Ma, K-T. (2020). Digital Transformation to Empower Smart Production for Industry 3.5 and an Empirical Study for Textile Dyeing. Computers and Industrial Engineering, 142, 106-120. https://doi.org/10.1016/j.cie.2020.106297.

Kuncoro, M. (2013). Indonesia's Textile and Its Products Industry: Recent Development and Challenges. International Journal of Business and Economic Development, 1(3), 60-75.

Padilha, C. K., \& Gomes, G. (2016). Innovation Culture and Performance in Innovation of Products and Processes: a Study in Companies of Textile Industry. RAI Revista de Administração e Inovação, 13(4), 285-294. https://doi.org/10.1016/j.rai.2016.09.004.

Parrish, E., Berdine, M., Cassill, N., \& Oxenham, W. (2008). Measuring the Competitive Advantage of the US Textile and Apparel Industry. in Industry Studies Conference Paper. https://doi.org/10.2139/ssrn.1134985.

Porter, M. E. (1998). The Competitive Advantage of Nations: With a New Introduction. New York: The Free Press.

Sabonien, A., Masteikien, R., \& Venckuvien, V. (2014). Exogenous Factors of the Textilerelated Low-tech Industries Competitiveness in Lithuania. Procedia - Social and Behavioral Sciences, 156, 298-303. https://doi.org/10.1016/j.sbspro.2014.11.192.

Salvatore, D. (2014). Ekonomi Internasional, 9th ed (International Economics). Jakarta: Salemba Empat.

Shen, B., \& Li, Q. (2019). Green Technology Adoption in Textile Supply Chains with Environmental Taxes: Production, Pricing, and Competition. IFAC-PapersOnLine, 52(13), 379-384. https://doi.org/10.1016/j.ifacol.2019.11.153

Shihab, M., \& Jain, S. K. (2004). The Preparedness of the Indonesian Garment Exporters in the Post-MFA Scenario: An Analysis from the Survey. Gadjah Mada International Journal of Business, 6(3), 383-404. https://doi.org/10.22146/gamaijb.5555.

Susilo, S. (2013). ASEAN Economic Community Implementation and Indonesian Textile Industry Competitiveness. Economic Journal of Emerging Markets, 5(2), 120-135. https://doi.org/10.20885/ejem.vol5.iss2.art5.

Tambunan, T. T. H. (2008). Daya Saing Global Indonesia 2008-2009 versi World Economic Forum [WEF] (Indonesian Global Competitiveness 2008-2009 according to the World Economic Forum [WEF]). Working Paper. Kadin Indonesia. 
Dwi Prasetyani. The Prospect and The Competitiveness of Textile Commodities

Wahyuni, S., \& Boeditomo, P. T. (2015). Does the Quality of Work Life Influence Competitiveness? A Comparison between Indonesia and Vietnam. Global Business and Management Research: An International Journal, 7(1), 32-59.

Zhao, H., \& Lin, B. (2020). Impact of Foreign Trade on energy efficiency in China's textile industry. Journal of Cleaner Production, 245,10-16. https://doi.org/10.1016/j.jclepro. 2019.118878 .

Zuhdi, F., \& Suharno, S. (2015). Analisis Daya Saing Ekspor Kopi Indonesia dan Vietnam di Pasar ASEAN 5 (Analysis of the Competitiveness of Indonesian and Vietnamese Coffee Exports in the ASEAN Market 5). Habitat, 26(3), 152-162. https://doi.org/10.21776/ ub.habitat.2015.026.3.18. 